Article

\title{
Catalytic Activity of Sulfated and Phosphated Catalysts towards the Synthesis of Substituted Coumarin
}

\author{
Nagi R. E. Radwan ${ }^{1,2, *}$, Mohamed Hagar ${ }^{1,3}$, Tarek H. Afifi ${ }^{4}$, Fahd Al-wadaani ${ }^{4}$ and \\ Rawda M. Okasha ${ }^{4}$ \\ 1 Chemistry Department, College of Science, Taibah University, Yanbu 30799, Saudi Arabia; \\ mhagar@taibahu.edu.sa \\ 2 Chemistry Department, College of Science, Suez University, Suez 41522, Egypt \\ 3 Chemistry Department, Faculty of Science, Alexandria University, Alexandria 21321, Egypt \\ 4 Chemistry Department, College of Science, Taibah University, Al-Medina Al-Munwarrah 30002, \\ Saudi Arabia; tmahmoud@taibahu.edu.sa (T.H.A.); fwadaani@taibahu.edu.sa (F.A.-w.); \\ rokasha@taibahu.edu.sa (R.M.O.) \\ * Correspondence: nagi_r_e@yahoo.com or nradwan@taibahu.edu.sa; Tel.: +966-545-520-236
}

Received: 6 December 2017; Accepted: 16 January 2018; Published: 19 January 2018

\begin{abstract}
New modified acidic catalysts were prepared from the treatment of silica, titania and silica prepared from hydrolyzed tetraethyl orthosilicate (TEOS) with sulfuric and phosphoric acid. The sulfated and phosphated silica synthesized from TEOS were calcined at 450 and $650{ }^{\circ} \mathrm{C}$. These catalysts were characterized by X-ray diffraction (XRD), Fourier-transform infrared spectroscopy (FTIR), transmission electron microscope (TEM), and scanning electron microscope (SEM). The surface areas, total pore volume, and mean pore radius of the acidic catalysts were investigated, while the pore size distribution was determined by the Barrett, Joyner and Halenda (BJH) method. The catalytic activity of the sulfated and phosphated silica and/or titania were examined with the Pechmann condensation reaction, in which different phenols reacted with ethyl acetoacetate as a neat reaction to obtain the corresponding coumarin derivatives. The results indicated that the treatment of the catalysts with sulfuric or phosphoric acid led to a decrease in the phases' crystallinity to a certain degree. The morphology and the structure of the acidified catalysts were examined and their particle size was calculated. Furthermore, the amount of the used catalysts played a vital role in controlling the formation of the products as well as their performance was manipulated by the number and nature of the active acidic sites on their surfaces. The obtained results suggested that the highest catalytic conversion of the reaction was attained at $20 \mathrm{wt} \%$ of the catalyst and no further increase in the product yield was detected when the amount of catalyst exceeded this value. Meanwhile the phenol molecules were a key feature in obtaining the final product.
\end{abstract}

Keywords: silica; titania; calcination process; surface modification; catalytic activity; coumarin derivatives

\section{Introduction}

Acidic solid catalysts are considered to be an important class of heterogeneous catalysts, particularly in the synthesis of pharmaceutical scaffolds [1]. Several advantages have been achieved using acidic solid catalysts such as their nonhazardous nature, selectivity, requirement in catalytic amounts and easier reaction conditions. Moreover, this class of catalysts can simply be retrieved and recycled, which classify these reactions as some of the green synthetic methodologies [2]. Amongst the abundant solid catalysts, sulfated metal oxides received more attention in recent years as potential catalysts for numerous reactions [3]. In comparison to acidic liquid catalysts, solid catalysts were found 
to be less corrosive and environmentally friendly. Several factors can contribute to the performance of the catalysts, like their chemical composition and structural features, which subsequently rule their active sites and influence the accessibility of the molecules to their pore size [4].

Coumarin as a heterocyclic motif is a significant scaffold in both industrial and pharmaceutical applications. Coumarin derivatives containing benzopyrones structure [5,6] are important heterocyclic organic compounds used in different applications such as the food industry [7], pharmaceuticals [8], as precursors for organic compounds [9], cosmetics [10], optical brighteners [11], and anticoagulants $[12,13]$. Coumarins have also merged into various biological purposes such as antibacterial [14] anticancer [15], antimicrobial [16], antioxidant [17-19] and antiinhibitor [20,21].

The synthesis of coumarin molecules has been established using different approaches such as Pechmann condensation [22-25], Perkin reaction [26-28], Witting reaction [29-31], Claisen rearrangement [32], Reformatsky reaction [33], Knoevenagel condensation [34-37], and flash vacuum pyrolysis [38]. Among the mentioned methods, the Pechmann reaction remains one of the most successful techniques to synthesize coumarin compounds. This methodology encompasses the condensation of phenols with $\beta$-ketoesters in the presence of various acidic agents such as sulfuric acid [22], aluminum chloride [39], phosphorus pentoxide [40], or trifluoroacetic acid [41]. The progress of the reactions required plentiful amounts of these acidic catalysts, and they cannot be retrieved or reused. For that matter, many researchers continue to aim their attention towards the development of simple, cheap, retrieved and/or recyclable catalysts for synthesizing coumarins. For instance, Sripathi and Logeeswari [42] used ultrasound in obtaining coumarin derivatives through the reaction of phenyl acetyl chloride and salicylaldehyde. Meanwhile, Zareyee and Serehneh [43] employed CMK-5 adapted by sulfonic acid as a catalyst to synthesize coumarin from substituted phenols and ethylacetoacetate. Other reports explored successful attempts of using sulfonated magnetic nanoparticles in forming coumarin derivatives [44,45]. Sulfonated mesoporous silica has also been utilized to prepare 7-hydroxy-4-methyl coumarin [46]. The catalytic activity of zirconium, titanium and tin metal phosphate and tungestate has been assessed for a Pechmann condensation reaction of phenols and methyl acetoacetate [47]. Sulfated zirconia supported on silica $\left(\mathrm{SiO}_{2}-\mathrm{SZ}\right)$ and unsupported sulfated zirconia (SZ) have been used as acidic solid catalysts for measuring the catalytic activity of the esterification reaction between lauric acid and palmitic acid [48], while phosphated zirconia has been employed as a catalyst for the condensation reaction of phenols and ethyl acetoacetate to achieve coumarin derivatives [25]. Furthermore, microwave has been used to prepare coumarin derivatives in the presence of sulfated zirconia, commercial sulfonic acid resin or amberlite-15 [25,49]. Silica gel has also impregnated with sulfuric acid to work as acidic solid catalysts for isolating coumarin derivatives under a solvent free solution [50].

Even though there are several studies addressing the catalytic performance of a variety of heterogeneous solid catalysts in producing coumarin compounds via Pechmann condensation, most of these methodologies suffer from some drawbacks such as long reaction time, swelling tendency, low surface area, stability of the catalysts and their costs [51-57]. In order to overcome some of these obstacles and as a continuation to our research in developing a new and efficient catalytic protocol for the effective synthesis of coumarins, this report elucidates the synthesis of three new catalytic systems of sulphated and phosphated nanoparticle of silica, titania and silica prepared from TEOS catalysts. The catalytic activity of the prepared catalysts was investigated for the synthesis of coumarin derivatives as neat reactions between phenols and ethyl acetoacetate. Our results demonstrated that the performance of the catalysts was controlled by the number and nature of the active acidic sites on their surface, whereas the employed phenol molecules have played a significant role in obtaining the final product. 


\section{Results and Discussion}

\subsection{Synthesis and X-ray Diffraction Patterns (XRD)}

The synthesis of the sulfated and phosphated silica and titania catalysts was achieved via the interaction of their suspension solution with the corresponding acidic media. However, the third modified silica catalyst was initially synthesized through the heating of the acidic tetraethyl orthosilicate (TEOS) solution to $100{ }^{\circ} \mathrm{C}$ for three days in the presence of cetyltrimethyl ammonium bromide (CTAB). The obtained $\mathrm{SiO}_{2}$ gel was modified with the sulfate and phosphate moieties followed by a calcination process at 450 and $650{ }^{\circ} \mathrm{C}$.

$\mathrm{X}$-ray diffraction was utilized to verify the success of the modification process of the three catalysts. Figure 1 illustrates the XRD patterns of the silica, titania and synthesized silica catalysts, as well as their sulfated and phosphated analogues. Inspection of these figures revealed the presence of the $\mathrm{SiO}_{2}$, anatase $\mathrm{TiO}_{2}$ and $\mathrm{SiO}_{2}$ phases prepared from TEOS, respectively. The characteristic lines of these phases and the intensities of their peaks are affected by the sulfate and phosphate groups.

The XRD diffraction peaks of the silica samples $\left(\mathrm{SiO}_{2}, \mathrm{SiO}_{2}-\mathrm{S}\right.$ and $\left.\mathrm{SiO}_{2}-\mathrm{P}\right)$ appeared as a broad halo at $2 \theta=22.9^{\circ}$ due to the amorphous silica phase, Figure $1 \mathrm{~A}$. The absence of sharp peaks in the $\mathrm{X}$-ray diffractogram is attributed to the amorphous nature of these solid catalysts, while the existence of the fine particles with a small crystallite size led to the formation of the poor crystalline $\mathrm{SiO}_{2}$ phase. The particle sizes were calculated using Scherrer equation, which displayed values of 28.5, 23, and $26.7 \mathrm{~nm}$, for $\mathrm{SiO}_{2}, \mathrm{SiO}_{2}-\mathrm{S}$ and $\mathrm{SiO}_{2}-\mathrm{P}$, respectively. On the contrary, the XRD patterns of the titania samples $\left(\mathrm{TiO}_{2}, \mathrm{TiO}_{2}-\mathrm{S}\right.$ and $\left.\mathrm{TiO}_{2}-\mathrm{P}\right)$ displayed diffraction peaks located at $2 \theta=25.3^{\circ}, 37.8^{\circ}, 48.1^{\circ}, 53.9^{\circ}$, $55.1^{\circ}, 62.7^{\circ}$ and $75.1^{\circ}$ that correspond to the crystalline anatase titania $\left(\mathrm{TiO}_{2}\right)$ phase as a major phase, JCPDS Card No: 21-1272 (JCPDS Catalogue), Figure 1B. While their particle sizes were found to be 395, 215 and $372 \mathrm{~nm}$, for $\mathrm{TiO}_{2}, \mathrm{TiO}_{2}-\mathrm{S}$ and $\mathrm{TiO}_{2}-\mathrm{P}$, respectively.

Figure 1C shows three broad diffraction peaks located at $2 \theta=22.5^{\circ}$ that correspond to the amorphous nature of the silica phase that is produced from the TEOS-S with calcination at $650{ }^{\circ} \mathrm{C}$ and the TEOS-P solid samples with calcination at 450 and $650^{\circ} \mathrm{C}$. In the meantime, the XRD pattern of the TEOS-S solid samples that calcined at $450^{\circ} \mathrm{C}$ exhibited diffraction peaks at $2 \theta=20.5^{\circ}, 21.5^{\circ}$, $26.4^{\circ}, 49.5^{\circ}, 59.4^{\circ}$, and $67.2^{\circ}$ which refers to its crystalline $\mathrm{SiO}_{2}$ phase. Calculation of the particle size demonstrated values of 163, $22 \mathrm{~nm}$ and 20.3, $21 \mathrm{~nm}$ for TEOS-S and TEOS-P calcined at 450, $650{ }^{\circ} \mathrm{C}$, respectively.
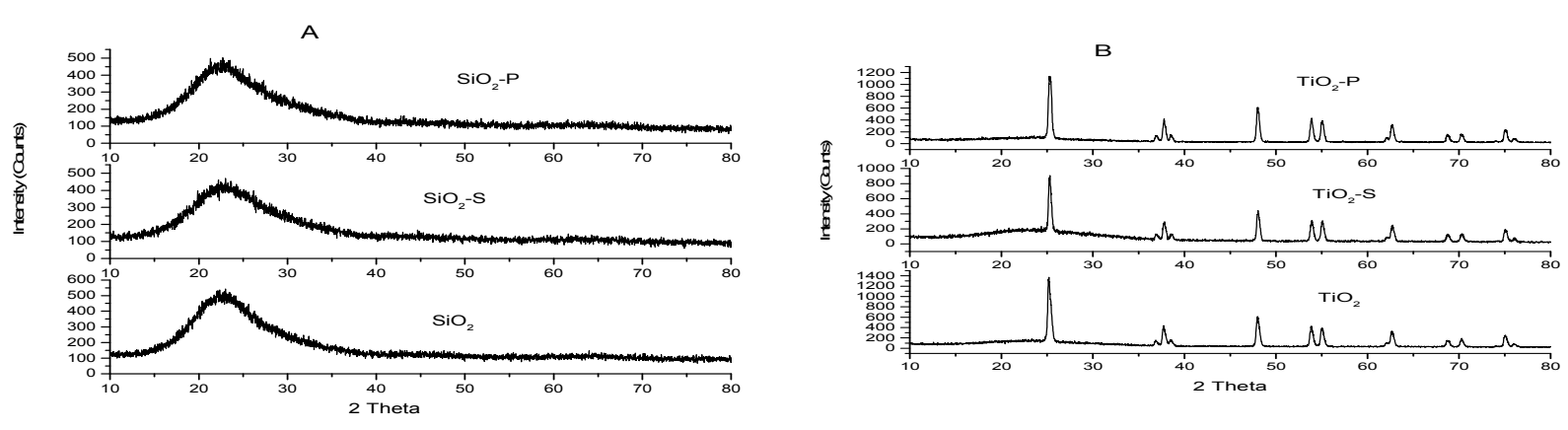

Figure 1. Cont. 


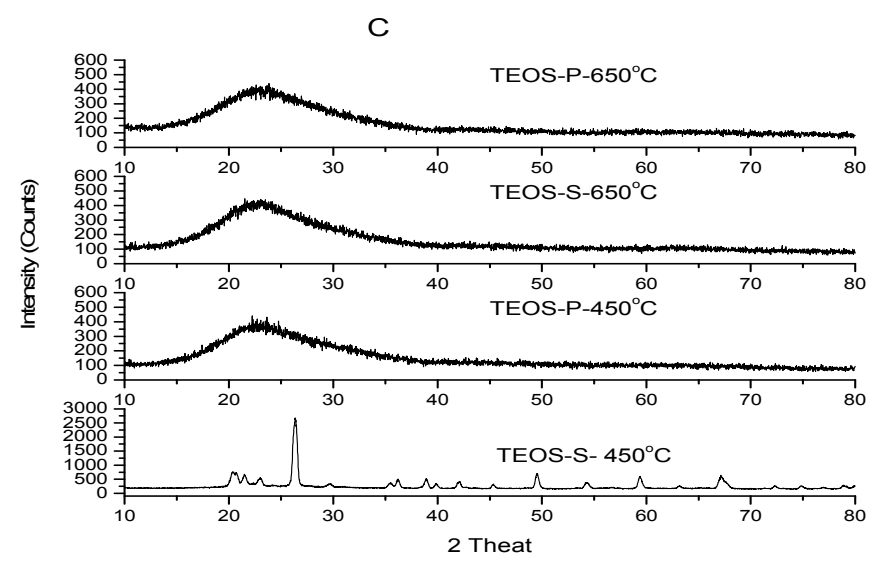

Figure 1. X-ray diffraction patterns of (A) $\mathrm{SiO}_{2}$ and its treatment with sulfuric and phosphoric acid; (B) $\mathrm{TiO}_{2}$ and its treatment with sulfuric and phosphoric acid; and (C) $\mathrm{SiO}_{2}$ obtained by hydrolysis of TEOS treated with sulfuric and phosphoric acid calcined at 450 and $650{ }^{\circ} \mathrm{C}$.

\subsection{FTIR Spectra of Samples}

The treatment of the catalytic samples with sulfuric or phosphoric acid resulted in a decrease of the relative intensity of the diffraction lines of the $\mathrm{SiO}_{2}$ and $\mathrm{TiO}_{2}$ phases. This was supported by measuring the peak's height of the main diffraction lines and their particle size. The values of the peak's height and the particle size are given in Table 1. The obtained data indicated that the modification of the target samples with sulfuric or phosphoric acid led to a changing in the peak's height of the main diffraction lines and a decrease in the crystallite size of the particles. This behavior suggests that the presence of the sulfate or the phosphate linkage can alter the surface and the catalytic properties of the solid catalysts.

Table 1. Surface areas, total pore volume and average pore radius of solid catalysts determined by Brunauer-Emmett-Teller (BET) and Barrett, Joyner and Halenda (BJH) methods.

\begin{tabular}{|c|c|c|c|c|c|c|c|}
\hline Sample & $\mathrm{S}_{\text {BET }} \mathrm{m}^{2} / \mathrm{g}$ & $\mathrm{S}_{\mathrm{t}} \mathrm{m}^{2} / \mathrm{g}$ & $S_{t} \mathrm{~m}^{2} / g$ & $V_{p}$ BET $\mathrm{cm}^{3} / g$ & $V_{p} B J H \mathrm{~cm}^{3} / g$ & $\mathrm{r}_{\text {BET }} \AA$ & $\mathrm{r}_{\mathrm{BJH}} \AA$ \\
\hline $\mathrm{SiO}_{2}$ & 308.5 & 308.5 & 352.7 & 0.801 & 0.819 & 52.0 & 54.1 \\
\hline $\mathrm{SiO}_{2}-\mathrm{S}$ & 244.6 & 344.6 & 468.8 & 0.636 & 0.741 & 52.0 & 37.0 \\
\hline $\mathrm{SiO}_{2}-\mathrm{P}$ & 285.8 & 285.8 & 476 & 0.696 & 0.787 & 48.7 & 29.2 \\
\hline $\mathrm{TiO}_{2}$ & 10.4 & 10.4 & 12.2 & 0.031 & 0.031 & 59.4 & 4.3 \\
\hline $\mathrm{TiO}_{2}-\mathrm{S}$ & 30.6 & 19.3 & 32.4 & 0.045 & 0.044 & 29.8 & 4.8 \\
\hline $\mathrm{TiO}_{2}-\mathrm{P}$ & 36.4 & 22.5 & 38.6 & 0.052 & 0.048 & 26.5 & 4.1 \\
\hline TEOS-S- $450^{\circ} \mathrm{C}$ & 20.8 & 20.8 & 50.7 & 0.102 & 0.116 & 98.3 & 19.6 \\
\hline TEOS-P- $450^{\circ} \mathrm{C}$ & 50.3 & 50.3 & 103.5 & 0.118 & 0.144 & 46.8 & 11.1 \\
\hline TEOS-S-650 ${ }^{\circ} \mathrm{C}$ & 20 & 20 & 35.7 & 0.061 & 0.068 & 133.7 & 18.6 \\
\hline TEOS-P-650 ${ }^{\circ} \mathrm{C}$ & 767.4 & 441.3 & 890.8 & 0.664 & 0.696 & 34.6 & 34.9 \\
\hline
\end{tabular}

Major chemical groups of the solid catalysts were identified by FTIR in the region of 4000-400 $\mathrm{cm}^{-1}$ and are shown in Figure S1, Supplementary Materials. The catalyst structure gives different types of oxygen atoms that display IR bands between 1100 and $400 \mathrm{~cm}^{-1}$, and the location of these peak depends on the arrangement of the oxygen atoms in the structure. For example, Figure S1A indicates the spectra of $\mathrm{SiO}_{2}$ and its treatment with $\mathrm{H}_{2} \mathrm{SO}_{4}$ and $\mathrm{H}_{3} \mathrm{PO}_{4}$ acid. The bands within the range $900-1050 \mathrm{~cm}^{-1}$ are assigned to the $\mathrm{Si}-\mathrm{OH}$. Therefore, the strong band at $1050 \mathrm{~cm}^{-1}$ is assigned to the stretching vibration mode of $\mathrm{Si}-\mathrm{O}-\mathrm{H}$. This peak is overlapped or partially overlapped with the $\mathrm{S}-\mathrm{OH}$ stretching vibration from the $\mathrm{HSO}_{4}{ }^{-}$ion for the sulfated silica. The IR peak around $800 \mathrm{~cm}^{-1}$ is attributed to the Si-O stretching vibration. A low peak observed near $576 \mathrm{~cm}^{-1}$ refers to the Si-O-Si stretching mode, while the peak observed near $450 \mathrm{~cm}^{-1}$ refers to the Si-O-Si out of plan bending mode, and the band located at $1620 \mathrm{~cm}^{-1}$ is assigned to the bending of water. 
The FTIR spectra of the titanium samples measured in the range of $4000-400 \mathrm{~cm}^{-1}$ are presented in Figure S1B. The spectra of the $\mathrm{TiO}_{2}$ displayed bands at $1050 \mathrm{~cm}^{-1}$ which are assigned to the Ti-O stretching vibration. $\mathrm{TiO}_{2}$ has bands presented in the range of $700-500 \mathrm{~cm}^{-1}$ due to the vibration of TiO-TiO bond, while the sulfated titania showed a broad absorbance band at $565 \mathrm{~cm}^{-1}$ that revealed the anatase form of $\mathrm{TiO}_{2}$ as confirmed by the XRD studies. Also, the peaks at $985-1120 \mathrm{~cm}^{-1}$ displayed the stretching of the $\mathrm{S}=\mathrm{O}$ band that supports the formation of sulphated $\mathrm{TiO}_{2}$. The phosphated titania revealed no characteristic peaks in the range of $400-800 \mathrm{~cm}^{-1}$ that indicated the absence of the P-O-P bond. Therefore, it is concluded that since the phosphorus is incorporated into the framework of mesoporous $\mathrm{TiO}_{2}$ by forming Ti-O-P bonds, there is no $\mathrm{PO}_{4}{ }^{3-}$ or polyphosphoric acid attached to the $\mathrm{TiO}_{2}$ surface. The spectra also exhibited a change in the intensity of the absorption peak due to the adsorption of the phosphate or sulfate ions on the surface of the solid catalysts.

Figure $\mathrm{S} 1 \mathrm{C}$ indicates the spectra of $\mathrm{SiO}_{2}$ prepared from hydrolyzed TEOS and its treatment analogous with $\mathrm{H}_{2} \mathrm{SO}_{4}$ and $\mathrm{H}_{3} \mathrm{PO}_{4}$ acid. The bands around $802 \mathrm{~cm}^{-1}$ refer to the Si-O-Si symmetrical mode, while the bands in the regions $1030-1095 \mathrm{~cm}^{-1}$ correspond to the $\mathrm{Si}-\mathrm{O}-\mathrm{Si}$ asymmetrical stretching mode, which overlaps with the S-OH stretching vibration from the $\mathrm{HSO}_{4}{ }^{-1}$ ion. The band located at $470 \mathrm{~cm}^{-1}$ is assigned to the Si-O-Si bending mode. The peaks that appeared at $1190 \mathrm{~cm}^{-1}$ in the sulfated silica Si-S spectra are attributed to the $\mathrm{SO}_{2}$ symmetrical stretching mode, while the peak located at $1070 \mathrm{~cm}^{-1}$ belongs to the $\mathrm{SO}_{2}$ asymmetrical stretching mode. Finally, the band at $690 \mathrm{~cm}^{-1}$ is assigned to the $-\mathrm{SO}_{3} \mathrm{H}$ formed on the surface on the treatment with the corresponding acid.

\subsection{SEM of Catalysts}

Scanning electron microscope (SEM) was used to examine the microstructure character of the solid catalysts. Figures 2 and 3 illustrate the morphology of the $\mathrm{SiO}_{2}, \mathrm{TiO}_{2}$ and the $\mathrm{SiO}_{2}$ obtained from the hydrolyzed TEOS. Most of the solid samples varied in their grain sizes, whereas some samples exhibited spherical shapes of different sizes. Also it can be seen that the treatment of the samples with the required acid caused a morphological transformation from small spherical structures to large particles. For instance, the size of the silica samples changed from $17.5 \mu \mathrm{m}$ to $30 \mu \mathrm{m}$, while the size of the titania samples changed from $1.2 \mu \mathrm{m}$ to $10 \mu \mathrm{m}$, and the silica obtained from the TEOS ranged from $5.9 \mu \mathrm{m}$ to $44 \mu \mathrm{m}$.
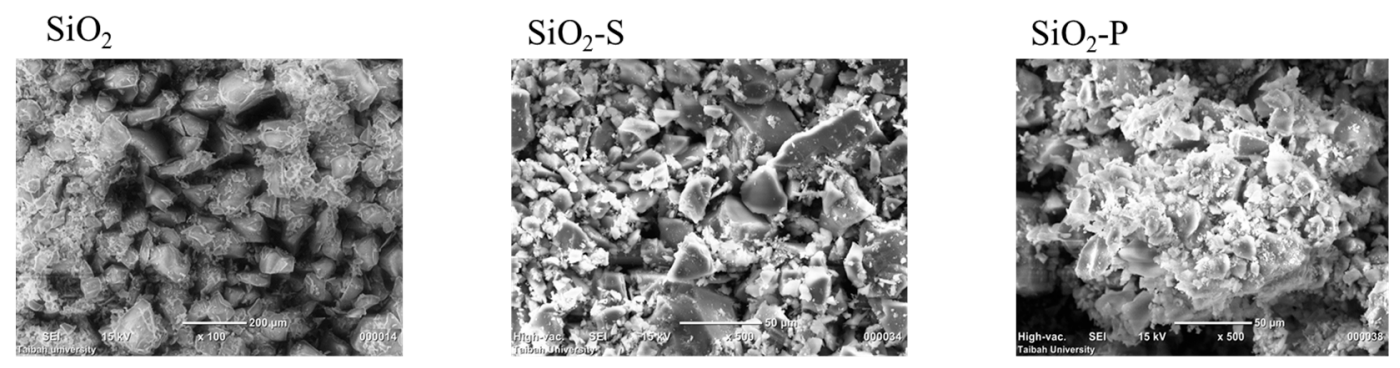

$\mathrm{TiO}_{2}$

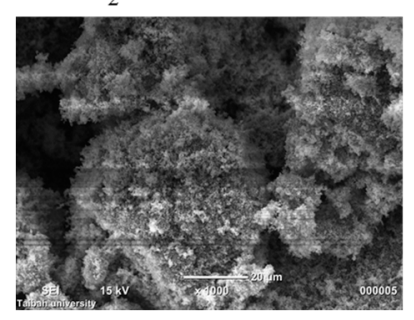

$\mathrm{TiO}_{2}-\mathrm{S}$

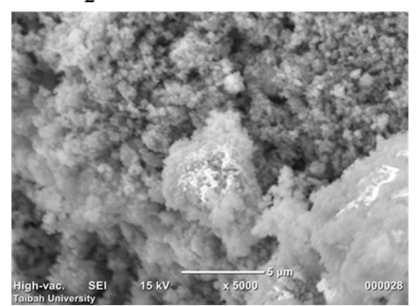

$\mathrm{TiO}_{2}-\mathrm{P}$

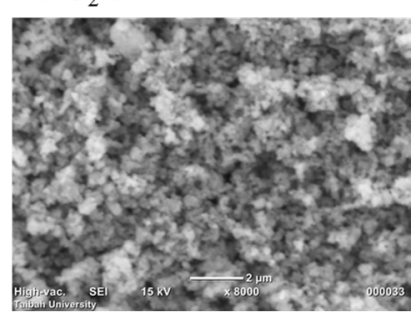

Figure 2. SEM microphotograph of silica, sulfated silica, phosphated silica, titania, sulfated titania, and phosphated titania. 


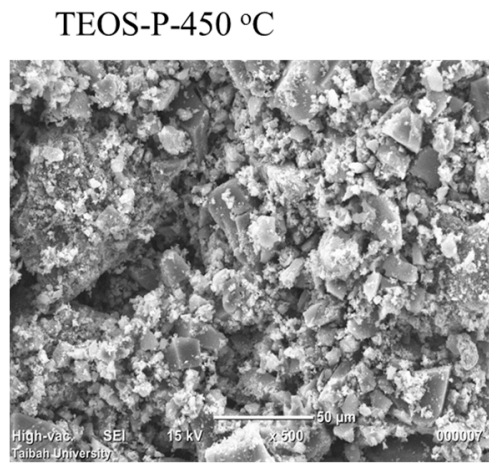

TEOS-P-650 ${ }^{\circ} \mathrm{C}$

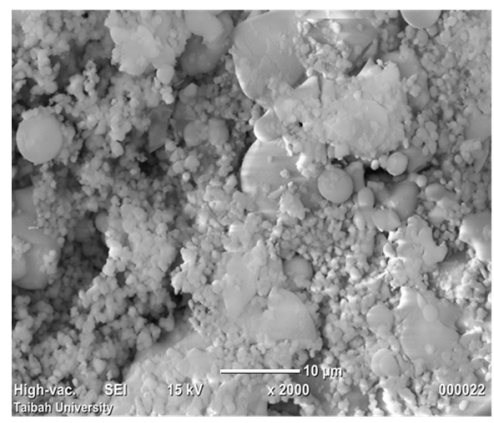

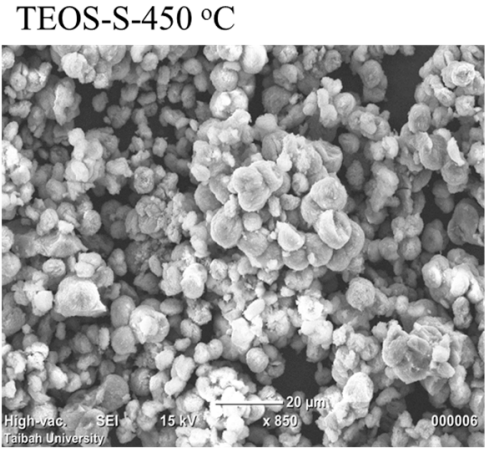

TEOS-S- $650^{\circ} \mathrm{C}$

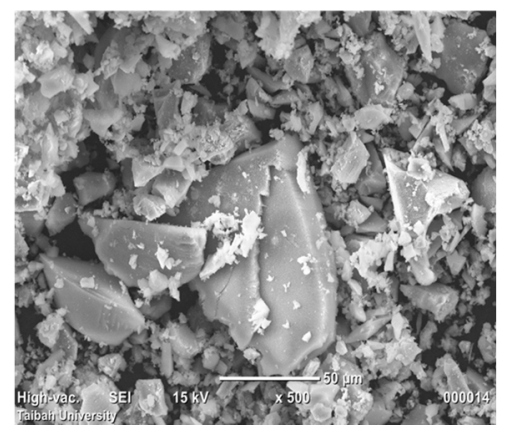

Figure 3. SEM microphotograph of silica prepared from TEOS treated with sulfuric and phosphoric acid calcined at 450 and $650{ }^{\circ} \mathrm{C}$.

\subsection{TEM of Catalysts}

Transmission electron microscopy was used to investigate the structure of the solid catalysts. The TEM images of the silica and the titania samples were depicted in Figure 4, while Figure 5 displays the images of the silica prepared from hydrolyzed TEOS with calcination at 450 and $650{ }^{\circ} \mathrm{C}$. The TEM images confirmed the well-shaped nanosized mesophase and the spherical structure of the silica and titania catalysts. The particles of the silica are spherical with a diameter ranging from 17.5 to $30 \mathrm{~nm}$, while titania particles displayed sizes ranging from 81.8 to $94.2 \mathrm{~nm}$, and the silica obtained from TEOS has particles with sizes between 9.4 and $43 \mathrm{~nm}$. These values showed good agreement with the previous data obtained from the Scherrer equation. The particle size was affected by the linkage type as well as the calcination temperature. It was also noticed that the modification process with the sulfated and phosphated groups led to partial aggregation of the catalysts' particles, which allowed the formation of larger clusters. 


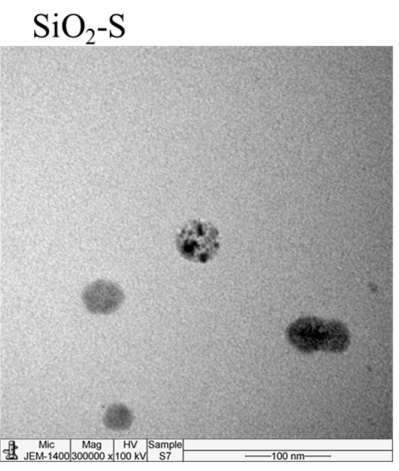

\section{$\mathrm{TiO}_{2}-\mathrm{S}$}

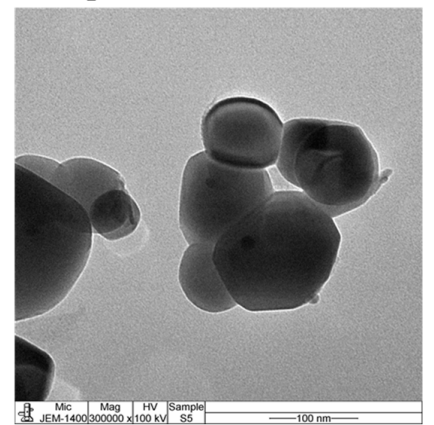

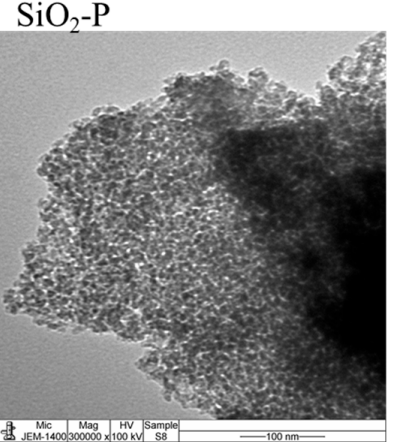

$\mathrm{TiO}_{2}-\mathrm{P}$

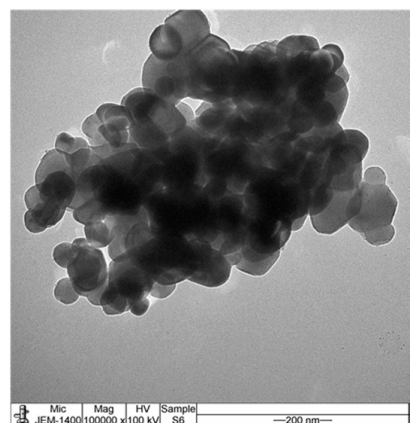

Figure 4. Transmission electron micrographs of sulfated silica, phosphated silica, sulfated titania, and phosphated titania.

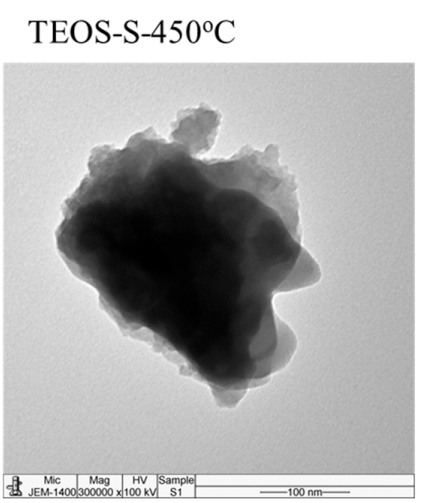

TEOS-S- $650^{\circ} \mathrm{C}$

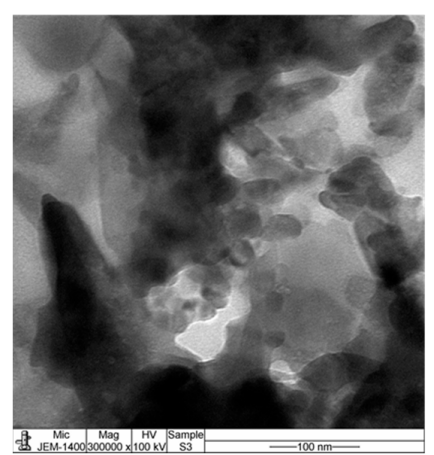

TEOS-P- $450^{\circ} \mathrm{C}$

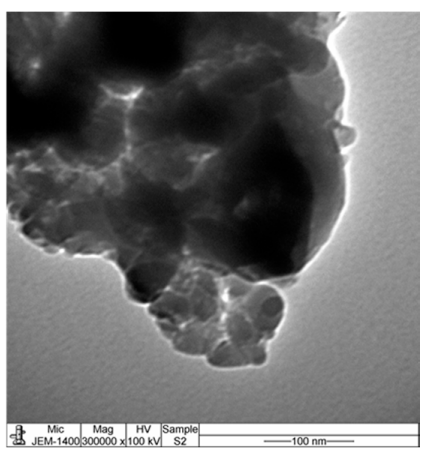

TEOS-P- $650^{\circ} \mathrm{C}$

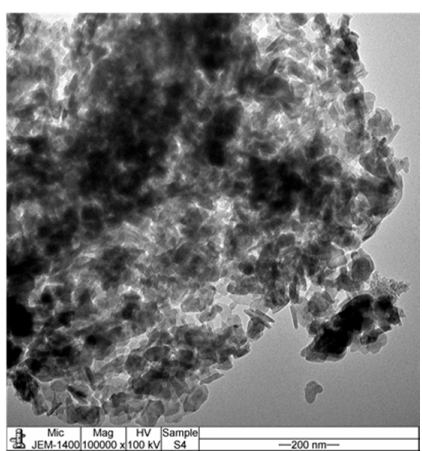

Figure 5. Transmission electron micrographs of silica prepared from TEOS treated with sulfuric and phosphoric acid and calcined at 450 and $650^{\circ} \mathrm{C}$. 


\subsection{Surface Area Measurements of the Catalysts}

Nitrogen adsorption-desorption isotherms of the three different catalysts are shown in Figure $6 \mathrm{~A}-\mathrm{C}$. The textural characters of the solid catalysts such as surface area, total pore volume and pore size were measured and are provided in Table 1 . These values were calculated using BET, BJH, and $\mathrm{t}$-methods.
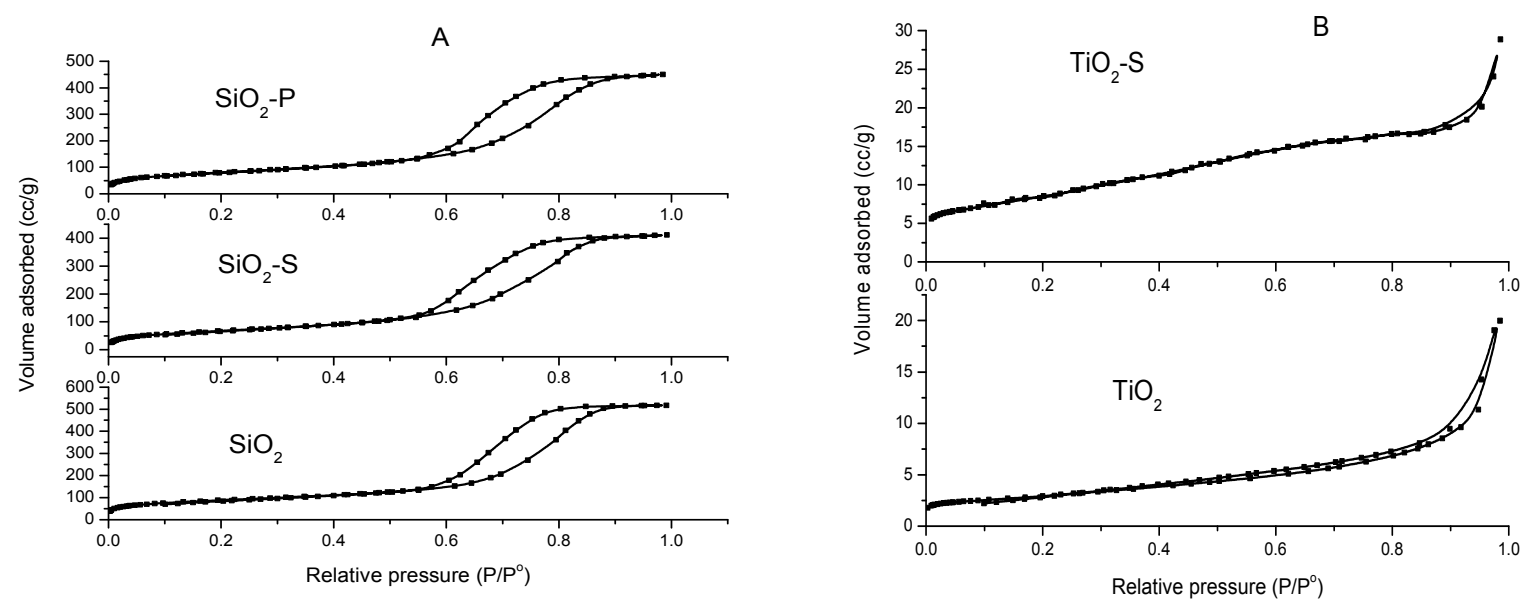

C

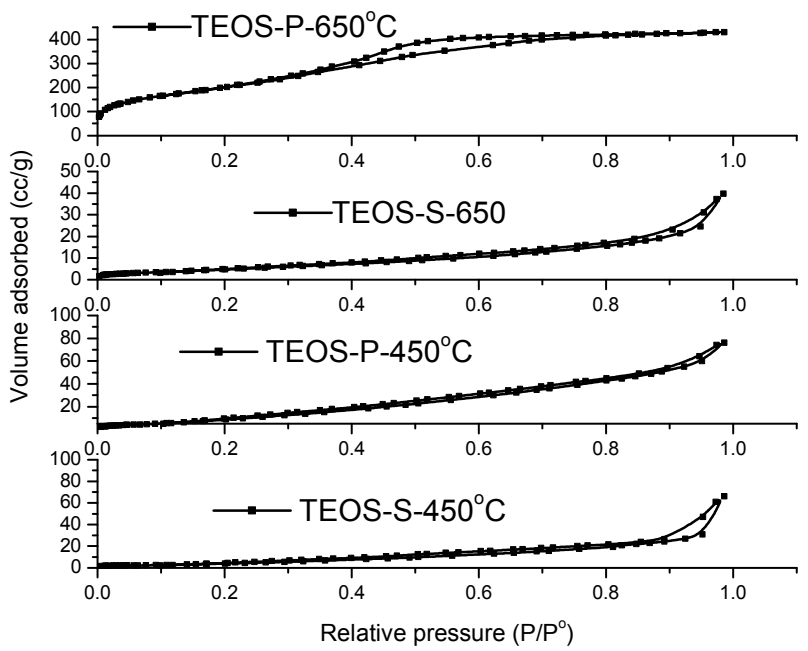

Figure 6. Nitrogen adsorption-desorption isotherm of different catalysts. Plot (A) silica, sulfated silica, and phosphated silica; plot (B) titania, and sulfated titania; plot (C) silica prepared from TEOS treated with sulfuric and phosphoric acid calcined at 450 and $650{ }^{\circ} \mathrm{C}$.

In general, the treatment of the catalysts has manipulated their characteristics. For instance, the specific surface area decreased when the samples were treated with sulfuric acid, and increased by their treatment with phosphoric acid. The increase of the surface area is more pronounced for the silica obtained from TEOS and was modified with phosphoric acid then calcined at $650{ }^{\circ} \mathrm{C}$. It was also observed that the specific surface area of the amorphous solid samples is higher than that of the crystalline solids. Noticeably, a similar trend was perceived by comparing the surface area of the samples calculated by different methods. Titania catalyst and its treatment with acids has a lower surface area than the silica and the silica catalyst prepared from TEOS. The surface area of the solid acid catalysts, calculated by diverse approaches follows the order silica $>$ silica prepared from TEOS $>$ titania.

The total pore volume of the solid catalysts calculated by the different procedures is provided in Table 1. According to the obtained data, the pore volume of the solid samples decreased on their 
treatment with the acid. In the meantime, Figure 7 illustrates the pore size distribution of the solid catalyst determined using the $\mathrm{BJH}$ method, and the data is given in Table 1.
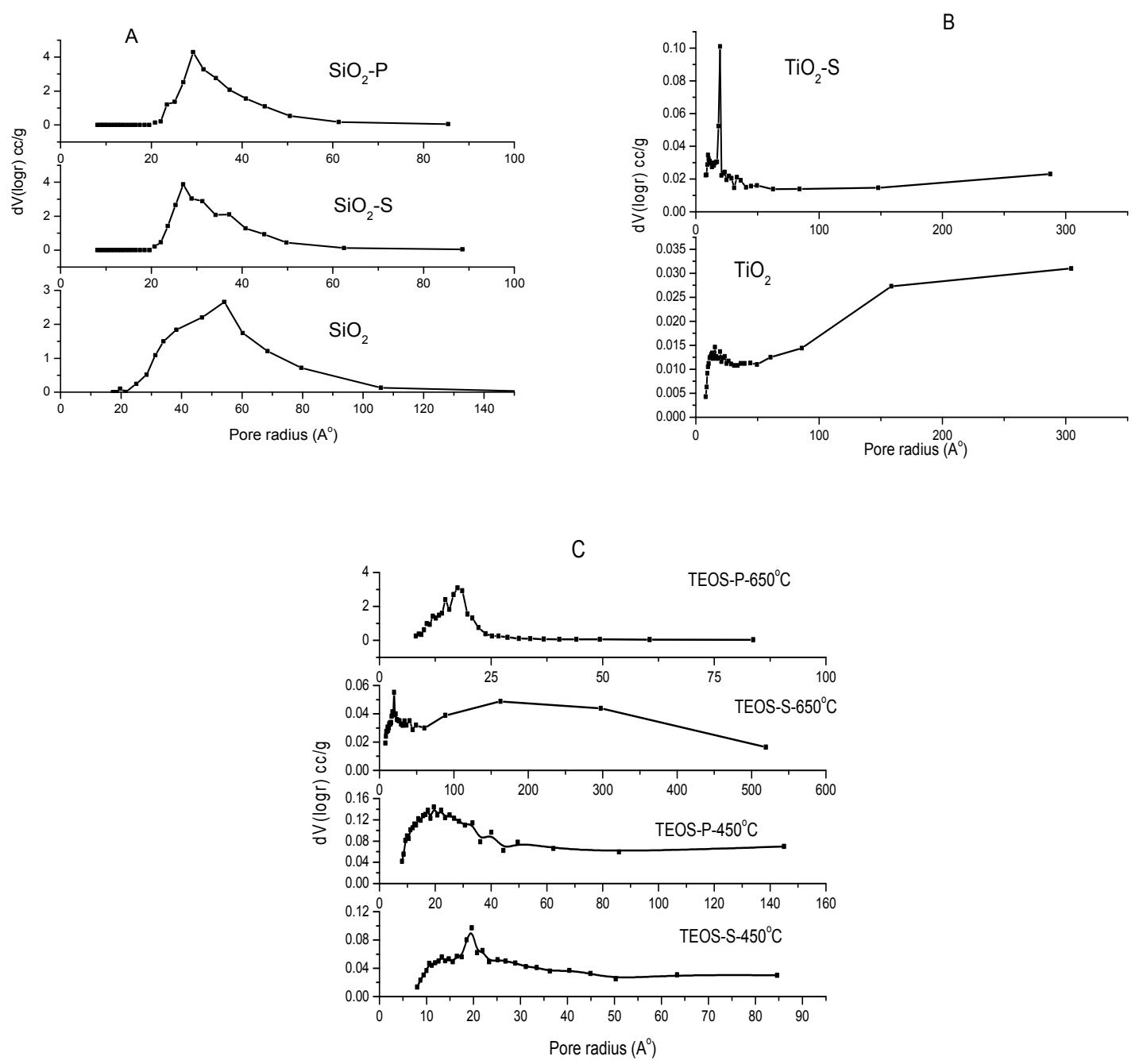

Figure 7. Pore size distribution BJH curves of different catalysts: plot (A) silica, sulfated silica and phosphated silica; plot (B) titania and sulfated titania; plot (C) silica prepared from TEOS treated with sulfuric and phosphoric acid calcined at 450 and $650{ }^{\circ} \mathrm{C}$.

\subsection{Catalytic Activity of the Catalysts}

The catalytic activity of the sulfated and phosphated silica $\left(\mathrm{SiO}_{2}-\mathrm{S}, \mathrm{SiO}_{2}-\mathrm{P}\right)$, titania $\left(\mathrm{TiO}_{2}-\mathrm{S}, \mathrm{TiO}_{2}-\mathrm{P}\right)$, and silica prepared from hydrolyzed TEOS $\left(\mathrm{SiO}_{2}-\mathrm{S}-450{ }^{\circ} \mathrm{C}, \mathrm{SiO}_{2}-\mathrm{P}-450{ }^{\circ} \mathrm{C}, \mathrm{SiO}_{2}-\mathrm{S}-650{ }^{\circ} \mathrm{C}, \mathrm{SiO}_{2}-\mathrm{P}-650\right.$ ${ }^{\circ} \mathrm{C}$ ) was measured through the Pechmann condensation reaction, Scheme 1 . The conversion percentage of the reaction between phenol derivatives and ethyl acetoacetate to produce the corresponding coumarin derivatives was calculated. Meanwhile, the effect of the catalyst weight was studied from 10 to $25 \mathrm{wt} \%$ relative to the amount of the resorcinol in the condensation reaction, as indicated in Figure 8. The effect of the reaction time on the catalytic activity of the solid catalysts was studied at $10 \mathrm{wt} \%$ catalyst relative to the amount of the resorcinol in the condensation reaction, as indicated in Figure 9. 


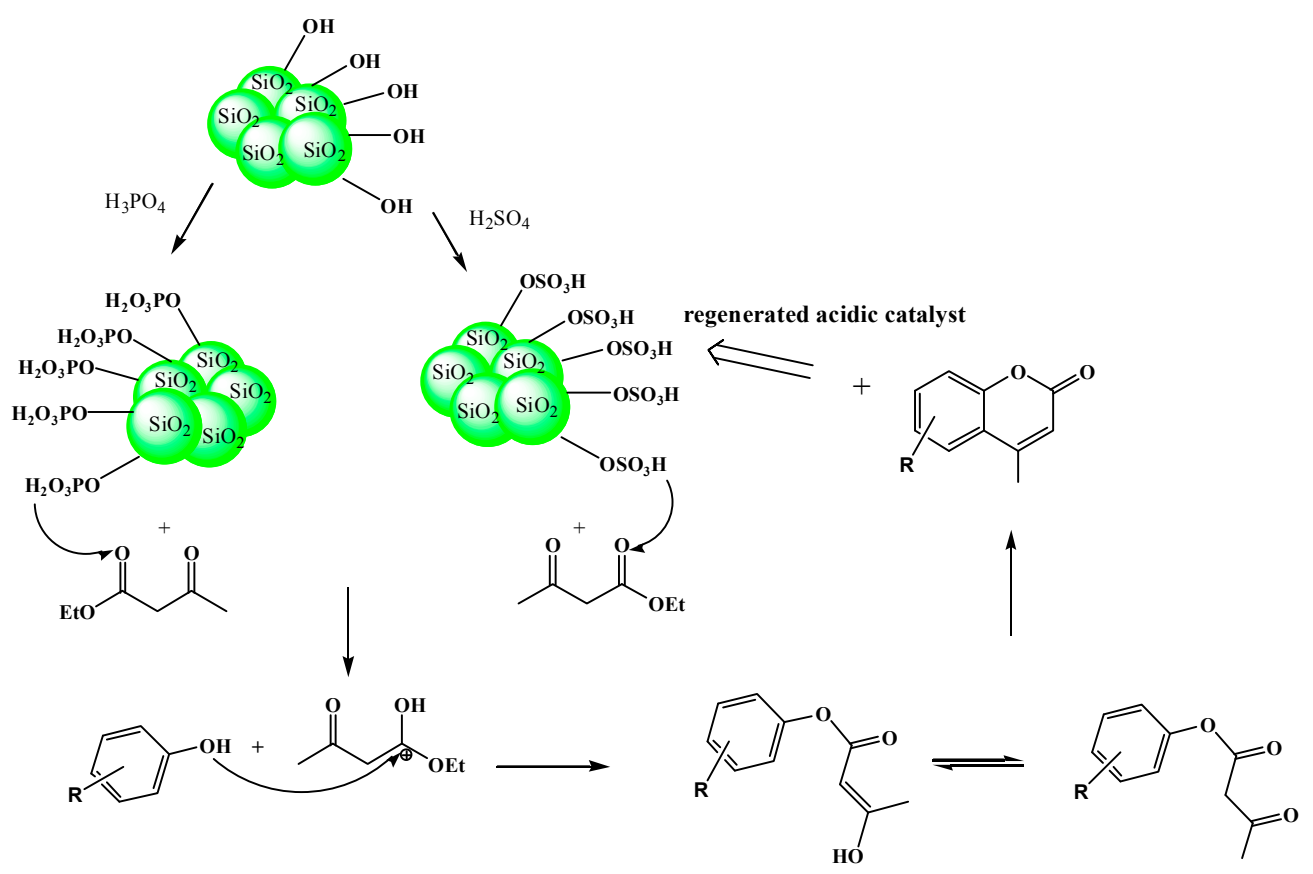

Scheme 1. Pechmann reaction.
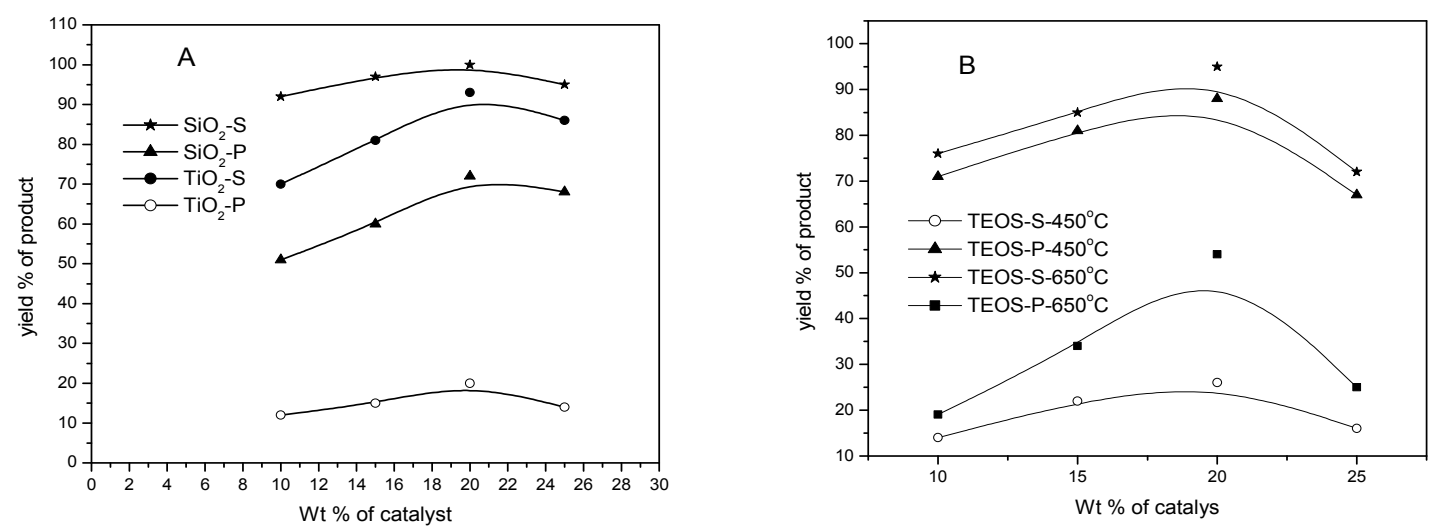

Figure 8. Effect of weight catalysts on yield \% of product for reaction of resorcinol and ethyl acetoacetate at reaction time $4 \mathrm{~h}$. Plot (A) sulfated and phosphate silica and titania; plot (B) silica prepared from TEOS treated with sulfuric and phosphoric acid calcined at 450 and $650{ }^{\circ} \mathrm{C}$.

The maximum yield of the product was obtained at the optimal amount of the catalyst $20 \mathrm{wt} \%$, where the amount of the catalyst is an important factor in determining the catalytic conversion of the catalyst; the highest catalytic conversion was obtained at $20 \mathrm{wt} \%$ of the catalyst and no further conversion was observed beyond this amount.

The increase of the amount of the catalysts led to an increase in their dispersion in the reaction mixture, and subsequently, their active sites became more accessible to the reactant molecules; therefore, the catalytic conversion increased and attained the maximum value. On the other hand, a further increase in the amount of the catalyst resulted in the occurrence of the side chain reaction and decreased the formation of the coumarin products. 

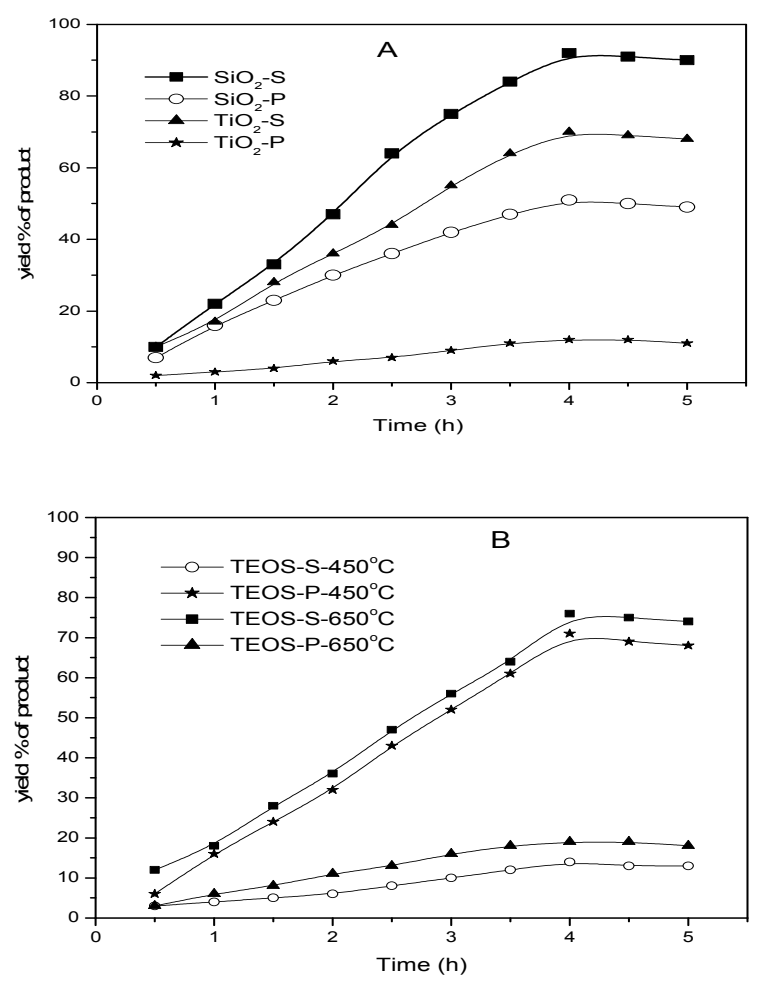

Figure 9. Plot of yield \% of product versus reaction time for reaction of resorcinol and ethyl acetoacetate using different catalysts, with amount $10 \mathrm{wt} \%$. Plot (A) sulfated and phosphate silica and titania, plot (B) silica prepared from TEOS treated with sulfuric and phosphoric acid calcined at 450 and $650{ }^{\circ} \mathrm{C}$.

It is important to note that the conversion percentage of the reaction over the sulfated silica and titania catalysts was discovered to be greater than their phosphated counterparts $\left(\mathrm{SiO}_{2}-\mathrm{S}>>\mathrm{SiO}_{2}-\mathrm{P}\right.$, $\mathrm{TiO}_{2}-\mathrm{S}>>\mathrm{TiO}_{2}-\mathrm{P}$ ). However, the conversion percentage of the reaction over the sulfated $\mathrm{SiO}_{2}$ prepared from TEOS catalysts was found to be lower than its phosphated form with calcination at $450{ }^{\circ} \mathrm{C}$ (TEOS-S- $450{ }^{\circ} \mathrm{C}<<$ TEOS-P- $450{ }^{\circ} \mathrm{C}$ ), while the sulfated $\mathrm{SiO}_{2}$ prepared from TEOS established a higher conversion than its phosphate analogue at $650{ }^{\circ} \mathrm{C}$ (TEOS-S- $650{ }^{\circ} \mathrm{C}>>$ TEOS-P-650 ${ }^{\circ} \mathrm{C}$ ). The catalyst weight percentage was kept constant at $20 \%$ during the reaction of pyrogallol, catechol, $\alpha$-naphthol, $\beta$-naphthol and phenol with ethyl acetoacetate, and the yield of product is reported in Table 2.

The number and nature of the active acidic sites on the surface of the catalysts play a critical role in the conversion process. The yield of the product increases with the increase of the catalyst amount where the number of active sites increases per gram of catalyst. Pechmann condensation could be proceeded via various possible mechanisms; for instance, the reaction could be initiated with the transesterification of phenol molecules with ethyl acetoacetate followed by the Michael addition reaction and then rearomatization to form the coumarin scaffold. The catalyst can be regenerated by a final dehydration [58]. Another proposed mechanism suggested that the metallic catalyst chelates with the ketoesters, followed by Friedel Craft cyclization to form an unstable anti-aromatic moiety which restores its aromaticity via the abstraction of a hydrogen atom. Transesterification and condensation then occurs to isolate the required product [2]. The condensation reaction of the substituted phenols with ethyl acetoacetate could also takes place through three steps: the transesterification step, intramolecular hydroxyalkylation step and dehydration step. The percentage of the catalytic conversion depends on the acidity of the catalyst's surface and the number of active sites [59-61]. 
Table 2. (A) The catalytic conversion for the reaction of phenol derivatives (5 $\mathrm{mM})$ and ethyl acetoacetate $(10 \mathrm{mM})$ over sulfated and phosphated silica and titania catalysts carried out at reaction temperature $200{ }^{\circ} \mathrm{C}$ and reaction time $4 \mathrm{~h}$ to produce coumarin derivatives. (B) The catalytic conversion for reaction of phenol derivatives $(5 \mathrm{mM})$ and ethyl acetoacetate $(10 \mathrm{mM})$ over sulfated and phosphated TEOS catalysts carried out at reaction temperature $200{ }^{\circ} \mathrm{C}$ and reaction time $4 \mathrm{~h}$ to produce coumarin derivatives.

\begin{tabular}{|c|c|c|c|c|c|}
\hline \multicolumn{6}{|c|}{$(\mathrm{A})$} \\
\hline Catalyst & $\begin{array}{l}\text { wt \% of } \\
\text { Catalyst }\end{array}$ & Phenol Type & Yield \% & $\begin{array}{c}\text { M.P }{ }^{\circ} \mathrm{C} \text { of } \\
\text { Product }\end{array}$ & $\begin{array}{c}\text { Theoritical } \\
\text { M.P }{ }^{\circ} \mathrm{C}[5,62]\end{array}$ \\
\hline- & 0 & Phenol derivatives & NR * & & \\
\hline $\mathrm{SiO}_{2}-\mathrm{S}$ & 20 & Resorcinol & 100 & \multirow{4}{*}{$186-187$} & \multirow{4}{*}{ 185-187 } \\
\hline $\mathrm{SiO}_{2}-\mathrm{P}$ & 20 & Resorcinol & 72 & & \\
\hline $\mathrm{TiO}_{2}-\mathrm{S}$ & 20 & Resorcinol & 93 & & \\
\hline $\mathrm{TiO}_{2}-\mathrm{P}$ & 20 & Resorcinol & 20 & & \\
\hline $\mathrm{SiO}_{2}-\mathrm{S}$ & 20 & Pyrogallol & 82 & \multirow{4}{*}{$242-244$} & \multirow{4}{*}{$242-243$} \\
\hline $\mathrm{SiO}_{2}-\mathrm{P}$ & 20 & Pyrogallol & 51 & & \\
\hline $\mathrm{TiO}_{2}-\mathrm{S}$ & 20 & Pyrogallol & 85 & & \\
\hline $\mathrm{TiO}_{2}-\mathrm{P}$ & 20 & Pyrogallol & 59 & & \\
\hline $\mathrm{SiO}_{2}-\mathrm{S}$ & 20 & $\beta$-Naphthol & 71 & \multirow{4}{*}{$181-182$} & \multirow{4}{*}{ 180-181 } \\
\hline $\mathrm{SiO}_{2}-\mathrm{P}$ & 20 & $\beta$-Naphthol & 63 & & \\
\hline $\mathrm{TiO}_{2}-\mathrm{S}$ & 20 & $\beta$-Naphthol & 51 & & \\
\hline $\mathrm{TiO}_{2}-\mathrm{P}$ & 20 & $\beta$-Naphthol & 44 & & \\
\hline $\mathrm{SiO}_{2}-\mathrm{S}$ & 20 & $\alpha$-Naphthol & 74 & \multirow{4}{*}{ 155-156 } & \multirow{4}{*}{$154-156$} \\
\hline $\mathrm{SiO}_{2}-\mathrm{P}$ & 20 & $\alpha$-Naphthol & 40 & & \\
\hline $\mathrm{TiO}_{2}-\mathrm{S}$ & 20 & $\alpha$-Naphthol & 60 & & \\
\hline $\mathrm{TiO}_{2}-\mathrm{P}$ & 20 & $\alpha$-Naphthol & 47 & & \\
\hline $\mathrm{SiO}_{2}-\mathrm{S}$ & 20 & Catechol & 47 & \multirow{4}{*}{ 193-195 } & \multirow{4}{*}{-} \\
\hline $\mathrm{SiO}_{2}-\mathrm{P}$ & 20 & Catechol & 43 & & \\
\hline $\mathrm{TiO}_{2}-\mathrm{S}$ & 20 & Catechol & 50 & & \\
\hline $\mathrm{TiO}_{2}-\mathrm{P}$ & 20 & Catechol & 28 & & \\
\hline $\mathrm{SiO}_{2}-\mathrm{S}$ & 20 & Phenol & 31 & \multirow{4}{*}{$79-81$} & \multirow{4}{*}{$78-80$} \\
\hline $\mathrm{SiO}_{2}-\mathrm{P}$ & 20 & Phenol & 9 & & \\
\hline $\mathrm{TiO}_{2}-\mathrm{S}$ & 20 & Phenol & 23 & & \\
\hline $\mathrm{TiO}_{2}-\mathrm{P}$ & 20 & Phenol & 7 & & \\
\hline \multicolumn{6}{|c|}{ (B) } \\
\hline- & 0 & Phenol derivatives & $\mathrm{NR}^{*}$ & & \\
\hline TEOS-S- $450{ }^{\circ} \mathrm{C}$ & 20 & Resorcinol & 26 & \multirow{4}{*}{$186-187$} & \multirow{4}{*}{$185-187$} \\
\hline TEOS-P-450 ${ }^{\circ} \mathrm{C}$ & 20 & Resorcinol & 95 & & \\
\hline TEOS-S- $650{ }^{\circ} \mathrm{C}$ & 20 & Resorcinol & 100 & & \\
\hline TEOS-P-650 ${ }^{\circ} \mathrm{C}$ & 20 & Resorcinol & 54 & & \\
\hline TEOS-S- $450{ }^{\circ} \mathrm{C}$ & 20 & Pyrogallol & 17 & \multirow{4}{*}{$242-244$} & \multirow{4}{*}{$242-243$} \\
\hline TEOS-P-450 ${ }^{\circ} \mathrm{C}$ & 20 & Pyrogallol & 70 & & \\
\hline TEOS-S-650 ${ }^{\circ} \mathrm{C}$ & 20 & Pyrogallol & 71 & & \\
\hline TEOS-P-650 ${ }^{\circ} \mathrm{C}$ & 20 & Pyrogallol & 47 & & \\
\hline TEOS-S- $450{ }^{\circ} \mathrm{C}$ & 20 & $\beta$-Naphthol & 49 & \multirow{4}{*}{$181-182$} & \multirow{4}{*}{$180-181$} \\
\hline TEOS-P-450 ${ }^{\circ} \mathrm{C}$ & 20 & $\beta$-Naphthol & 56 & & \\
\hline TEOS-S- $650{ }^{\circ} \mathrm{C}$ & 20 & $\beta$-Naphthol & 58 & & \\
\hline TEOS-P-650 ${ }^{\circ} \mathrm{C}$ & 20 & $\beta$-Naphthol & 60 & & \\
\hline TEOS-S- $450{ }^{\circ} \mathrm{C}$ & 20 & $\alpha$-Naphthol & 34 & & \\
\hline TEOS-P-450 ${ }^{\circ} \mathrm{C}$ & 20 & $\alpha$-Naphthol & 47 & & \\
\hline TEOS-S- $650{ }^{\circ} \mathrm{C}$ & 20 & $\alpha$-Naphthol & 60 & 155-156 & 154-156 \\
\hline TEOS-P-650 ${ }^{\circ} \mathrm{C}$ & 20 & $\alpha$-Naphthol & 50 & & \\
\hline TEOS-S- $450{ }^{\circ} \mathrm{C}$ & 20 & Catechol & 22 & & \\
\hline TEOS-P-450 ${ }^{\circ} \mathrm{C}$ & 20 & Catechol & 48 & & - \\
\hline TEOS-S $-650{ }^{\circ} \mathrm{C}$ & 20 & Catechol & 38 & 193-195 & - \\
\hline TEOS-P-650 ${ }^{\circ} \mathrm{C}$ & 20 & Catechol & 36 & & \\
\hline TEOS-S- $450{ }^{\circ} \mathrm{C}$ & 20 & Phenol & 6 & & \\
\hline TEOS-P-450 ${ }^{\circ} \mathrm{C}$ & 20 & Phenol & 7 & & \\
\hline TEOS-S $-650{ }^{\circ} \mathrm{C}$ & 20 & Phenol & 12 & 79-81 & $78-80$ \\
\hline TEOS-P-650 ${ }^{\circ} \mathrm{C}$ & 20 & Phenol & 10 & & \\
\hline
\end{tabular}


During the synthesis of coumarin, it was observed that the presence of more than one hydroxyl group on the phenol molecules increased the reactivity towards the ethyl acetoacetate and offered a high percentage yield. On the contrary, the presence of $\alpha$-naphthol, $\beta$-naphthol and phenol displayed less reactivity towards the ethyl acetoacetate to form the required coumarin as a result of the absence of any activating groups on the phenol ring. It is also important to note that this report explores the first successful attempt to use catechol as a precursor to synthesize coumarin molecules. However, catechol resulted in a low conversion percentage yield due to the presence of the ortho-hydroxyl group which deactivates carbon-6, in addition to the high possibility of forming hydrogen bonding.

The catalytic conversion of the proposed catalysts is controlled by the strength of the acidic sites and an increase in the surface area. Compared to previous reports [25,42-46,52-58], this study also demonstrated that the surface area of the catalytic systems can be manipulated by the synthetic methodology. As can be observed from the obtained data, the acidic $\mathrm{SiO}_{2}$ catalyst varies in the surface area in comparison to the one prepared from TEOS and displays more activity towards the Pechmann reaction. In addition, the calcination temperature of the $\mathrm{SiO}_{2}$ prepared from hydrolyzed TEOS played a crucial role in its catalytic activity and, consequently, in the percentage yield of the coumarin derivatives. One of the problems that was encountered during the progression of the reaction was the adsorption of some of the reactant molecules on the surface of the catalysts, which changed the color of the catalyst into brown and black shades and reduced the catalyst's activity. In order to recover the catalyst's surface, the reaction was treated with ethanol, which helped in the removal of the weakly adsorbed reactant molecules.

\section{Experimental}

\subsection{Materials}

Silica $\left(\mathrm{SiO}_{2}\right)$, titania $\mathrm{TiO}_{2}, \mathrm{H}_{2} \mathrm{SO}_{4}, \mathrm{H}_{3} \mathrm{PO}_{4}$, tetraethyl orthosilicate (TEOS), cetyltrimethyl ammonium bromide (CTAB), ethylacetoacetate, resorcinol, pyrogallol, phenol, $\alpha$-Naphtol, $\beta$-naphthol, catechol, were obtained from Sigma-Aldrich, Saint Louis, MO, USA. All chemicals used are of analytical grade.

\subsection{Catalysts Preparation}

\subsubsection{Sulfated Catalysts}

Sulfated silica and/or titania were prepared by adding $20 \mathrm{~mL}$ of acetone containing $2 \mathrm{~mL}$ of $\mathrm{H}_{2} \mathrm{SO}_{4}$ to a dispersion solution of $10 \mathrm{~g} \mathrm{SiO}_{2}$ and / or $10 \mathrm{~g}$ of titania in $60 \mathrm{~mL}$ acetone, then stirring for four hours at $30{ }^{\circ} \mathrm{C}$. The paste was dried in the oven at $100{ }^{\circ} \mathrm{C}$ for $24 \mathrm{~h}$ to remove the solvent. The dried solid was washed several times with water to get rid of the excess acid which was not adsorbed on the surface.

\subsubsection{Phosphated Catalysts}

Phosphated silica and/or titania catalysts were prepared following the same methodology for the sulfated catalysts using $2 \mathrm{~mL}$ of $\mathrm{H}_{3} \mathrm{PO}_{4}$ instead of sulfuric acid.

\subsubsection{Sulfated and/or Phosphated TEOS}

$\mathrm{SiO}_{2}$ gel formation was prepared by mixing $16.8 \mathrm{~mL}$ of TEOS to $300 \mathrm{~mL}$ of distilled water, $30 \mathrm{~mL}$ $\mathrm{HCl}(2 \mathrm{M})$ and $30 \mathrm{~mL}$ of ethanol, then add a solution containing $1.8 \mathrm{~g}$ of CTAB. The gel ratio of CTAB:HCl: $\mathrm{H}_{2} \mathrm{O}: T E O S$ was $2.5 \mathrm{mmol}: 6 \mathrm{~mol}: 10 \mathrm{~mol}: 0.02 \mathrm{~mol}$. The mixture was stirred for $6 \mathrm{~h}$ at $60^{\circ} \mathrm{C}$, and then transferred into closed vessel in an oven at $100{ }^{\circ} \mathrm{C}$ for three days. The solid product was obtained by filtration and washed with water several times until become free of chloride ions, then dried at $80^{\circ} \mathrm{C}$. Finally, the solid obtained was impregnated with $10 \mathrm{~mL}$ of $\mathrm{H}_{2} \mathrm{SO}_{4}$ and/or $10 \mathrm{~mL}$ of 
$\mathrm{H}_{3} \mathrm{PO}_{4}$ and stirred for $1 \mathrm{~h}$. The sulphated TEOS and/or phosphated TEOS paste was dried in an oven at $80^{\circ} \mathrm{C}$ for $12 \mathrm{~h}$ to remove the solvent. The solid samples were calcined at 450 and $650{ }^{\circ} \mathrm{C}$.

\subsection{Catalyst Characterization}

X-ray powder diffraction patterns (XRD) for the prepared catalyst samples was carried out on Shimadzu X-ray diffractometer 6000 (Kyoto, Japan) with $\mathrm{Cu}-\mathrm{K} \alpha$ radiation $(\lambda=1.5405 \AA$ ) in the $2 \theta$ range $10-80^{\circ}$ with a scanning rate of $2^{\circ} / \mathrm{min}$ for phase and crystallinity. The average particle size of the prepared catalysts was calculated from Scherrer equation [63], $d=(K \lambda) /\left(\beta_{1 / 2} \cos \theta\right)$, where $d$ is the mean diameter, $\lambda$ is the wavelength (1.540060 $\AA$ ), $K$ is the Scherrer constant $(0.89), \beta_{1 / 2}$ is full width half maximum (FWHM) of the diffraction peaks of $\mathrm{SiO}_{2}$ and $\mathrm{TiO}_{2}$, and $\theta$ is the diffraction angle.

The morphology and the SEM pictures of solid catalysts were taken by the Scanning Electron Microscope Super Scan SSX-550 Shimadzu (Kyoto, Japan). Transmutation electron microscope (TEM) imaged of solid catalyst samples and the particle size of these solid were investigated by JEOL JEM 1400 Transmission Electron Microscope instrument worked at $120 \mathrm{kV}$ (Akishima, Tokyo, Japan). The measurement was conducted by dissolving the solid samples in methyl alcohol and put in ultrasound radiation for $20 \mathrm{~min}$, then take a drop from suspension onto the grids of coated carbon. Surface area measurements of solid catalysts were investigated by nitrogen adsorption isotherms at $-196{ }^{\circ} \mathrm{C}$ using a NOVA 3200 apparatus, manufactured in Boynton Beach, FL, USA. The solid catalysts were heated under vacuum $\left(10^{-4}\right.$ Torr $)$ at $250^{\circ} \mathrm{C}$ for $2 \mathrm{~h}$. The specific surface area $S_{\text {BET }}$ of the samples was calculated with the BET equation. Pore size distribution were calculated using Barrett, Joyner and Halenda (BJH) method from the desorption branch of the isotherms.

\subsection{Capacity of Catalyst Activity}

To perform the catalyst activity, the coumarin synthesis was carried out in a $100 \mathrm{~mL}$ round bottom flask containing a known weight percent of catalyst with respect to $5 \mathrm{mmol}$ of phenols and $10 \mathrm{mmol}$ of ethyl acetoacetate under reflux at $200{ }^{\circ} \mathrm{C}$ for $4 \mathrm{~h}$. The reaction mixture was left to cool at room temperature, add a small amount of ethanol $(3 \mathrm{~mL})$, and pour it in a beaker containing $20 \mathrm{gm}$ of crushed ice. The resulting solution was filtered to separate the product and the catalyst, then the product was dissolved in 60-70 $\mathrm{mL}$ hot ethanol. The catalyst was again separated from the ethanolic solution of the product by filtration. The ethanolic solution was concentrated to precipitate the product, collected by filtration and recrystallized from ethanol to give pure coumarin. The product was characterized by thin layer chromatography (TLC) and the melting point measurement then the percentage yield was calculated. The melting point of the coumarin product produced from the reaction of the resorcinol with ethylacetoacetate was found to be between $186-187^{\circ} \mathrm{C}$, while the melting points of the other products are given in Table 2. It is important to note that there is good agreement between the measured melting point values and their theoretical counterparts [5,63].

\section{Conclusions}

Three different catalysts of $\mathrm{SiO}_{2}, \mathrm{TiO}_{2}$ and $\mathrm{SiO}_{2}$ prepared from TEOS were synthesized and their surfaces were modified through their reactions with sulfuric and phosphoric acids. The new catalysts were characterized using XRD diffraction which revealed that the phases of the silica catalysts are affected by the presence of the sulfate and phosphate groups, while the XRD diffraction peaks of the titania samples indicated the presence of the crystalline anatase titania phase as a major phase.

Among the obtained catalysts, phosphated silica prepared from TEOS and calcined at $650{ }^{\circ} \mathrm{C}$ had the highest surface area compared to the other catalysts. On the contrary, titania catalysts displayed the lowest surface area. The surface area of the acidified catalysts was calculated using different procedures.

Utilizing the new catalysts in the production of coumarin molecules, it was established that the sulfated silica and titania catalysts succeeded in isolating the highest yield of the desired products compared to their phosphated form $\left(\mathrm{SiO}_{2}-\mathrm{S}>>\mathrm{SiO}_{2}-\mathrm{P}, \mathrm{TiO}_{2}-\mathrm{S}>>\mathrm{TiO}_{2}-\mathrm{P}\right)$. In contrast, the sulfated silica prepared from TEOS at $450{ }^{\circ} \mathrm{C}$ showed lower catalytic activity than its phosphated counterpart 
(TEOS-S- $450{ }^{\circ} \mathrm{C}<<$ TEOS-P- $450{ }^{\circ} \mathrm{C}$ ), while the sulfated one at $650{ }^{\circ} \mathrm{C}$ illustrated higher catalytic activity than its phosphate analogue (TEOS-S- $6500^{\circ} \mathrm{C}>>$ TEOS-P- $650^{\circ} \mathrm{C}$ ). Finally, the yield of coumarin product depends on the amount of catalyst used where the catalytic conversion is determined by the number and the strength of the acidic sites of the catalysts.

Supplementary Materials: The following are available online at www.mdpi.com/2073-4344/8/1/36/s1, Figure S1: FTIR spectra of: (A) $\mathrm{SiO}_{2}$ and treated with sulfuric acid $\mathrm{SiO}_{2}-\mathrm{S}$ and phosphoric acid $\mathrm{SiO}_{2}-\mathrm{P}$, (B) $\mathrm{TiO}_{2}$ and its treatment with sulfuric acid $\mathrm{TiO}_{2}-\mathrm{S}$ and phosphoric acid $\mathrm{TiO}_{2}-\mathrm{P}$, and (C) silica prepared from TEOS treated with sulfuric and phosphoric acid calcined at 450 and $650^{\circ} \mathrm{C}$.

Acknowledgments: The authors gratefully acknowledge the Deanship of Scientific Research, Taibah University for the support of this research work, project No. 6049.

Author Contributions: N.R.E.R., M.H., T.H.A. and F.A.-w. conceived and designed the experiments; N.R.E.R., M.H., T.H.A., F.A.-w. and R.M.O. performed the experiments; analyzed the data and wrote the paper. All authors discussed the results and commented on the manuscript.

Conflicts of Interest: The authors declare no conflict of interest.

\section{References}

1. Sarvari, H.-M.; Sodagar, E.; Doroodmand, M.M. Nano sulfated titania acid catalyst in direct synthesis of fatty acid amides. J. Org. Chem. 2011, 76, 2853-2859. [CrossRef] [PubMed]

2. Khan, S.A.; Khan, S.B.; Asiri, A.M.; Ahmad, I. Zirconia-based catalyst for the one-pot synthesis of coumarin through Pechmann reaction. Nanoscale Res. Lett. 2016, 11, 345. [CrossRef] [PubMed]

3. Shi, W.; Li, J. A deactivation mechanism of sulfated titania in the esterification of acetic acid and n-butanol. React. Kinet. Mech. Catal. 2014, 11, 215-233. [CrossRef]

4. Goswami, P. Dually activated Organo- and Nano-cocatalyzed synthesis of coumarin derivatives. Synth. Commun. 2009, 39, 2271-2278. [CrossRef]

5. Bahekar, S.S.; Shinde, D.B. Samarium(III) catalyzed one-pot construction of coumarins. Tetrahedron Lett. 2004, 45, 7999-8001. [CrossRef]

6. Kumar, B.V.; Naik, H.S.B.; Girija, D. ZnO nanoparticle as catalyst for efficient green one-pot synthesis of coumarins through Knoevenagel condensation. J. Chem. Sci. 2011, 123, 615-621. [CrossRef]

7. Lake, B.G. Coumarin metabolism, toxicity and carcinogenicity: Relevance for human risk assessment. Food Chem. Toxicol. 1999, 37, 423-453. [CrossRef]

8. O'kennedy, R.; Thornes, R.D. Coumarins: Biology, Applications, and Mode of Action; Wiley and Sons: Chichester, UK, 1997.

9. Gunnewegh, E.A.; Hoefnagel, A.J.; van Bekkum, H. Zeolite catalysed synthesis of coumarin derivatives. J. Mol. Catal. A Chem. 1995, 100, 87-92. [CrossRef]

10. Bogdal, D. Coumarins: Fast Synthesis by Knoevenagel Condensation under Microwave Irradiation. J. Chem. Res. 1998, 468-469. [CrossRef]

11. Zahradnik, M. The Production and Application of Fluorescent Brightening Agents; John Wiley and Sons: New York, NY, USA, 1992.

12. Singer, L.A.; Long, N.P. Vinyl Radicals. Stereoselectivity in Hydrogen Atom Transfer to Equilibrated Isomeric Vinyl Radicals. J. Am. Chem. Soc. 1966, 88, 5213-5219. [CrossRef]

13. Weigt, S.; Huebler, N.; Strecker, R.; Braunbeck, T.; Broschard, T.H. Developmental effects of coumarin and the anticoagulant coumarin derivative warfarin on zebrafish (Danio rerio) embryos. Reprod. Toxicol. 2012, 33, 133-141. [CrossRef] [PubMed]

14. Kayser, O.; Kolodziej, H. Antibacterial Activity of Extracts and Constituents of Pelargonium sidoides and Pelargonium reniforme. Planta Med. 1997, 63, 508-510. [CrossRef] [PubMed]

15. Maly, D.J.; Leonetti, F.; Backes, B.J.; Dauber, D.S.; Harris, J.L.; Craik, C.S.; Ellman, J.A. Expedient Solid-Phase Synthesis of Fluorogenic Protease Substrates Using the 7-Amino-4-carbamoylmethylcoumarin (ACC) Fluorophore. J. Org. Chem. 2002, 67, 910-915. [CrossRef] [PubMed]

16. Kawase, M.; Varu, B.; Motohashi, N.; Tani, S.; Saito, S.; Debnath, S.; Mahapatra, S.; Dastidar, S.G.; Chakrabarty, A.N. Antimicrobial activity of new coumarin derivatives. Arzneimittelforschung 2001, 51, 67-71. [CrossRef] [PubMed] 
17. Garazd, M.M.; Muzychka, O.V.; Vovk, A.I.; Nagorichna, I.V.; Ogorodniichuk, A.S. Modified coumarins. 27. Synthesis and antioxidant activity of 3-substituted 5, 7-dihydroxy-4-methylcoumarins. Chem. Nat. Compd. 2007, 43, 19-23. [CrossRef]

18. Yun, B.S.; Lee, I.K.; Ryoo, I.J.; Yoo, I.D.J. Coumarins with Monoamine Oxidase Inhibitory Activity and Antioxidative Coumarino-lignans from Hibiscus syriacus. Nat. Prod. 2001, 64, 1238-1240. [CrossRef]

19. Tyagi, Y.K.; Kumar, A.; Raj, H.G.; Vohra, P.; Gupta, G.; Kumari, R.; Kumar, P.; Gupta, R.K. Synthesis of novel amino and acetyl amino-4-methylcoumarins and evaluation of their antioxidant activity. Eur. J. Med. Chem. 2005, 40, 413-420. [CrossRef] [PubMed]

20. Cheng, J.F.; Ishikawa, A.; Ono, Y.; Arrhenius, T.; Nadzan, A. Novel chromene derivatives as TNF- $\alpha$ inhibitors. Bioorg. Med. Chem. Lett. 2003, 13, 3647-3650. [CrossRef] [PubMed]

21. Whittaker, M.; Floyd, C.D.; Brown, P.; Gearing, A.J.H. Design and Therapeutic Application of Matrix Metalloproteinase Inhibitors. Chem. Rev. 1999, 99, 2735-2776. [CrossRef] [PubMed]

22. Kumar, S.; Saini, A.; Sandhu, J.S. LiBr-Mediated, solvent free von Pechmann reaction: Facile and efficient method for the synthesis of 2H-chromen-2-ones. Arkivoc 2007, 15, 18-23. [CrossRef]

23. Kumar, V.; Tomar, S.; Patel, R.; Yousaf, A.; Parmar, V.S.; Malhotra, S.V. FeCl 3 -Catalyzed Pechmann Synthesis of Coumarins in Ionic Liquids. Synth. Commun. 2008, 38, 2646-2654. [CrossRef]

24. Reddy, Y.T.; Sonar, V.N.; Crooks, P.A.; Dasari, P.K.; Reddy, P.N.; Rajitha, B. Ceric Ammonium Nitrate (CAN): An Efficient Catalyst for the Coumarin Synthesis via Pechmann Condensation using Conventional Heating and Microwave Irradiation. Synth. Commun. 2008, 38, 2082-2088. [CrossRef]

25. Sinhamahapatra, A.; Sutradhar, N.; Pahari, S.; Bajaj, H.C.; Panda, A.B. Mesoporous zirconium phosphate: An efficient catalyst for the synthesis of coumarin derivatives through Pechmann condensation reaction. Appl. Catal. A 2011, 394, 93-100. [CrossRef]

26. Perkin, W.H. III-On Propionic Coumarin and Some of its Derivatives. J. Chem. Soc. 1875, 28, 10-15. [CrossRef]

27. Maheswara, M.; Siddaiah, V.; Lakishmi, G.; Yerra, V.D.; Rao, K.; Rao, C.V. A solvent-free synthesis of coumarins via Pechmann condensation using heterogeneous catalyst. J. Mol. Catal. A Chem. 2006, 255, 49-52. [CrossRef]

28. Amoozadeh, A.; Ahmadzadeh, M.; Kolvari, E. Easy Access to Coumarin Derivatives Using Alumina Sulfuric Acid as an Efficient and Reusable Catalyst under Solvent-Free Conditions. J. Chem. 2013, 2013, 1-7. [CrossRef]

29. Yavari, I.; Hekmat-Shoar, R.; Zonouzi, A. A new and efficient route to 4-carboxymethyl coumarins mediated by vinyl triphenyl phosphonium salt. Tetrahedron Lett. 1998, 39, 2391-2392. [CrossRef]

30. Narasimhan, N.S.; Mali, F.S.; Barve, M.V. Synthetic Application of Lithiation Reactions; Part XIII. Synthesis of 3-Phenylcoumarins and Their Benzo Derivatives. Synthesis 1979, 39, 906-909. [CrossRef]

31. Upadhyay, P.K.; Kumar, P. A novel synthesis of coumarins employing triphenyl( $\alpha$-carboxymethylene) phosphorane imidazolide as a C-2 synthon. Tetrahedron Lett. 2009, 50, 236-238. [CrossRef]

32. Cairns, N.; Harwood, L.M.; David, P.; Astles, D.P. Tandem thermal Claisen-Cope rearrangements of coumarate derivatives. Total syntheses of the naturally occurring coumarins: Suberosin, demethylsuberosin, ostruthin, balsamiferone and gravelliferone. J. Chem. Soc. Perkin Trans. 1994, 1, 3101-3107. [CrossRef]

33. Karimi, B.; Zareyee, D. Design of a Highly Efficient and Water-Tolerant Sulfonic Acid Nanoreactor Based on Tunable Ordered Porous Silica for the von Pechmann Reaction. Org. Lett. 2008, 10, 3989-3992. [CrossRef] [PubMed]

34. Verdía, P.; Santamarta, F.; Tojo, E. Knoevenagel Reaction in [MMIm] [MSO 4$]$ : Synthesis of Coumarins. Molecules 2011, 16, 4379-4388. [CrossRef] [PubMed]

35. Khoshkholgh, M.J.; Lotfi, M.; Balalaie, S.; Rominger, F. Efficient synthesis of pyrano[2,3-c] coumarins via intramolecular domino Knoevenagel Hetero-Diels-Alder reactions. Tetrahedron 2009, 65, 4228-4234. [CrossRef]

36. Essien, E.R.; Olaniyi, O.A.; Adams, L.A.; Shaibu, R.O. Sol-Gel-Derived Porous Silica: Economic Synthesis and Characterization. J. Miner. Mater. Charact. Eng. 2012, 11, 976-981. [CrossRef]

37. Kalita, P.; Kumar, R. Solvent-free coumarin synthesis via Pechmann reaction using solid catalysts. Microporous Mesoporous Mater. 2012, 149, 1-9. [CrossRef]

38. Ghosh, A. An Efficient and Simple Procedure for the Synthesis of 4-Substituted Coumarins by von-Pechmann Reaction using Mixture of $\mathrm{FeCl}_{3}$ and Tetrabutylammonium bromide as Catalyst. Int. J. Sci. Res. 2016, 5, 974-976. [CrossRef] 
39. Sethna, S.M.; Shah, N.M.; Shah, R.C. Aluminium chloride, a new reagent for the condensation of $\beta$-ketonic esters with phenols. Part I. The condensations of methyl $\beta$-resorcylate, $\beta$-resorcylic acid, and resacetophenone with ethyl acetoacetate. J. Chem. Soc. 1938, 228-232. [CrossRef]

40. Robertson, A.; Sandrock, W.A.; Hendry, C.B. CCCXXX-Hydroxy-carbonyl compounds. Part V. The preparation of coumarins and 1:4-pyrones from phenol, p-cresol, quinol, and $\alpha$-naphthol. J. Chem. Soc. 1931, 2426-2432. [CrossRef]

41. Woods, L.L.; John Sapp, J. A New One-Step Synthesis of Substituted Coumarins. J. Org. Chem. 1962, 27, 3703-3705. [CrossRef]

42. Vekariya, R.H.; Patel, H.D. Recent Advances in the Synthesis of Coumarin Derivatives via Knoevenagel Condensation: A Review. Synth. Commun. 2014, 44, 2756-2788. [CrossRef]

43. Zareyee, D.; Serehneh, M. Recyclable CMK-5 supported sulfonic acid as an environmentally benign catalyst for solvent-free one-pot construction of coumarin through Pechmann condensation. J. Mol. Catal. A Chem. 2014, 391, 88-91. [CrossRef]

44. Samadizadeh, M.; Nouri, S.; Moghadam, F.K. Magnetic Nanoparticles Functionalized Ethan Sulfonic Acid (MNESA): As an Efficient Catalyst in the Synthesis of Coumarin Derivatives Using Pechman Condensation Under Mild Condition. Res. Chem. Intermed. 2016, 42, 6089-6103. [CrossRef]

45. Esfahani, F.K.; Zareyee, D.; Yousefi, R. Sulfonated Core-Shell Magnetic Nanoparticle $\left(\mathrm{Fe}_{3} \mathrm{O}_{4} @ \mathrm{SiO}_{2} @ \mathrm{PrSO}_{3} \mathrm{H}\right)$ As A Highly Active and Durable Protonic Acid Catalyst; Synthesis of Coumarin Derivatives Through Pechman Reaction. ChemCatChem 2014, 6, 3333-3337. [CrossRef]

46. Khder, A.S.; Ahmed, S.A.; Khairou, K.S.; Altass, H.M. Competent, Selective and High Yield of 7-hydroxy-4-methyl Coumarin over Sulfonated Mesoporous Silica as Solid Acid Catalysts. J. Porous Mater. 2017. [CrossRef]

47. Joshi, R.; Chudasama, U. Synthesis of Coumarins via Pechmann Condensation using inorganic ion exchangers as solid acid catalysts. J. Sci. Ind. Res. 2008, 67, 1092-1097.

48. Chen, X.R.; Ju, Y.H.; Mou, C.Y. Direct Synthesis of Mesoporous Sulfated Silica-Zirconia Catalysts with High Catalytic Activity for Biodiesel via Esterification. J. Phys. Chem. C 2007, 111, 18731-18737. [CrossRef]

49. Bouasla, S.; Amaro-Gahete, J.; Esquivel, D.; Lopez, M.I.; Jimenez-Sanchidrian, C.; Teguiche, M.; Romero-Salguero, F.J. Coumarin Derivatives Solvent-Free Synthesis under Microwave Irradiation over Heterogenous Solid Catalysts. Molecules 2017, 22, 2072. [CrossRef] [PubMed]

50. Tyagi, B.; Mishra, M.K.; Jasra, R.V. Microwave-assisted solvent free synthesis of hydroxy derivatives of 4-methyl coumarin using nano-crystalline sulfated-zirconia catalyst. J. Mol. Catal. A Chem. 2008, 286, 41-46. [CrossRef]

51. Opanasenko, M.; Shamzhy, M.; Cejka, J. Solid Acid Catalysts for Coumarin Synthesis by the Pechman Reaction: MOFs versus Zeolites. ChemCatChem 2013, 5, 1024-1031. [CrossRef]

52. Reddy, B.M.; Patil, M.K. Organic Syntheses and Transformations Catalyzed by Sulfated Zirconia. Chem. Rev. 2009, 109, 2185-2208. [CrossRef] [PubMed]

53. Liu, X.-Y.; Huang, M.; Ma, H.-L.; Zhang, Z.-Q.; Gao, J.-M.; Zhu, Y.-L.; Han, X.-J.; Guo, X.-Y. Preparation of a Carbon-Based Solid Acid Catalyst by Sulfonating Activated Carbon in a Chemical Reduction Process. Molecules 2010, 15, 7188-7196. [CrossRef] [PubMed]

54. Bose, D.S.; Rudradas, A.P.; Babu, M.H. The indium(III) chloride-catalyzed von Pechmann reaction: A simple and effective procedure for the synthesis of 4-substituted coumarins. Tetrahedron Lett. 2002, 43, 9195-9197. [CrossRef]

55. Manhas, M.S.; Ganguly, S.N.; Mukherjee, S.; Jian, A.K.; Bose, A.K. Microwave initiated reactions: Pechmann coumarin synthesis, Biginelli reaction, and acylation. Tetrahedron Lett. 2006, 47, 2423-2425. [CrossRef]

56. Rajabi, F.; Feiz, A.; Luque, R. An efficient synthesis of coumarin derivatives using a SBA-15 supported Cobalt(II) nanocatalyst. Catal. Lett. 2015, 145, 1621-1625. [CrossRef]

57. Khaligh, N.G. Synthesis of coumarins via Pechmann reaction catalyzed by 3-methyl-1-sulfonic acid imidazolium hydrogen sulfate as an efficient, halogen-free and reusable acidic ionic liquid. Catal. Sci. Technol. 2012, 2, 1633-1636. [CrossRef]

58. Atghia, S.V.; Beigbaghlou, S.S. Use of a Highly Efficient and Recyclable Solid-Phase Catalyst Based on Nanocrystalline Titania for the Pechmann Condensation. C. R. Chim. 2014, 1155-1159. [CrossRef]

59. Cullity, B.D. Elements of X-ray Diffraction, 3rd ed.; Addison-Wesley: Reading, MA, USA, 1967. 
60. Oyamada, J.; Chengguo, J.C.; Fujiwara, Y.; Kitamura, T. Direct Synthesis of Coumarins by Pd(II)-Catalyzed Reaction of Alkoxyphenols and Alkynoates. Chem. Lett. 2002, 31, 380-381. [CrossRef]

61. Naik, M.A.; Mishra, B.G.; Dubey, A. Combustion synthesized $\mathrm{WO}_{3}-\mathrm{ZrO}_{2}$ nanocomposites as catalyst for the solvent-free synthesis of coumarins. Colloids Surf. A 2008, 317, 234-238. [CrossRef]

62. Shirini, F.; Asieh Yahyazadeh, A.; Mohammadi, K. A solvent-free synthesis of coumarins using 1,3-disulfonic acid imidazolium hydrogen sulfate as a reusable and effective ionic liquid catalyst. Res. Chem. Intermed. 2015, 41, 6207-6218. [CrossRef]

63. Reddy, B.M.; Thirupathi, B.; Patil, M.K. One-Pot Synthesis of Substituted Coumarins Catalyzed by Silica Gel Supported Sulfuric Acid Under Solvent-Free Conditions. Open Catal. J. 2009, 2, 33-39. [CrossRef]

(C) 2018 by the authors. Licensee MDPI, Basel, Switzerland. This article is an open access article distributed under the terms and conditions of the Creative Commons Attribution (CC BY) license (http://creativecommons.org/licenses/by/4.0/). 